\title{
Upaya Meningkatkan Hasil Belajar Dengan Model Pembelajaran Kooperatif Pada Materi Pembelajaran Pecahan
}

\author{
Indah Marwati \\ SDN Tengki 01 Brebes \\ indah.marwati2@gmail.com
}

\section{Article History}

received 3/12/2020

\begin{abstract}
This research is motivated by the low student achievement in the fractional material. The students' learning outcomes in the material have not been able to reach the KKM. The purpose of this research is to determine the effect of the cooperative learning model. The subjects of this study were teachers and all grade II students of SDN Tengko 01, amounting to 24 students. This research was carried out in two cycles. The instruments used were lesson plans, question sheets, lesson plans analysis sheets and APKG sheets. Data collection techniques in this study used test techniques and observation techniques. The data analysis technique used was quantitative description. The results showed that the use of cooperative learning models can be used to improve student achievement. This is evidenced by changes in abilities and an increase in the average score obtained by students after improving learning. In cycle 1 the value is 69 and in cycle 2 it becomes 82. this number can be found say that there is an increase in student learning outcomes that are quite good, seen from the results of the cycle 1 test to the final results after learning.
\end{abstract}

Keywords: cooperative, learning outcomes, fractions

\begin{abstract}
Abstrak
Penelitian ini di latarbelakangi oleh rendahya prestasi belajar siswa pada materi pecahan hasil belajar siswa dalam materi tersebut belum mampu mencapai KKM.Tujuan dari adanya penelitian ini adalah mengetahui pengaruh model pembelajaran kooperatif.Subjek penelitian ini adalah guru dan seluruh siswa kelas II SDN Tengki 01 yang berjumlah 24 orang siswa.penelitian ini dilaksanakan dalam dua siklus, Instrumen yang di gunakan adalah RPP,Lembar soal,Lembar analisis RPP dan lembar APKG.Teknik pengumpulan data dalam penelitian ini menggunakan teknik tes dan teknik observasi.Adapun teknik analisis data yang digunkana adalah deskripsi kuantitaif.Hasil penelitian menunjukan bahwa penggunaan model pembelajaran kooperatif dapat digunakan untuk meningkatkan prestasi belajar siswa. Hal ini terbukti dengan adanya perubahan kemampuan dan meningkatnya nilai rata-rata yang diperoleh siswa setelah melakukan perbaikan pembelajaran.Pada siklus 1 nilainya 69 dan pada siklus 2 menjadi 82.dari angka ini dapat dikatakan bahwa ada peningkatan hasil belajar siswa yang cukup baik dilihat dari hasil tes siklus1 sampai hasil akhir setelah dilakukan perbaikan pembelajaran.
\end{abstract}

Kata kunci: kooperatif, hasil belajar, pecahan

Social, Humanities, and Education Studies (SHEs): Conference Series https://jurnal.uns.ac.id/shes

p-ISSN 2620-9284 e-ISSN 2620-9292 


\section{PENDAHULUAN}

Dalam kehidupan tentunya kita tidak asing dengan namanya perubahan begitu pula di bidang pendidikan ,yang akan selalu berubah seiring dengan perkembangan zaman.di Indonesia sejak di berlakukannya Undang undang Nomor 2 Tahun1989 tentang sistem pendidikan Nasional (UUSPN).Maka semua pendidikan yang ada di Indonesia harus mengacu pada Undang Undang tersebut.

Keberhasilan seorang guru dalam proses pembelajaran dapa di lihat seberapa jauh siswa mampu menguasai materi yag di ajarkan, namun tingkat kemampuan pemahaman peserta didik dalam menguasai materi tentulah berbeda antara yang satu dan yang lainnya , baik kemampuan kognitif,afektik, dan juga psoko motorik serta minat dan pemusatan perhatian sisswa pada proses pembelajaran.

Belajar menurut Dimyati dan Mudjiono (2006) : Belajar merupakan suatu proses internal yang kompleks, yang terlibat dalam proses internal tersebut adalah yang meliputi unsur afektif, dalam matra afektif berkaitan dengan sikap, nilai-nilai, interes, apresiasi, dan penyesuaian perasaan sosial.

Dalam kegiatan kooperatif peserta didik bekerja sama antara individu dengan individu yang lain untuk mencari hasil yang menguntungkan bagi seluruh anggota kelompoknya. Hal ini sesuai dengan yang dikatakan Burton yang dikutip Nasution (2000:148) dan dikutip lagi oleh Heri Gunawan, S.Pd.I., M.Ag., bahwa kooperatif atau kerjasama adalah cara individu mengadakan relasi dan bekerjasama dengan individu lain untuk mencapai tujuan bersama. Dari sini dapat dipahami, bahwa kooperatif adalah suatu strategi pembelajaran yang terdiri dari kelompok-kelompok untuk dimanfaatkan individu agar dapat memaksimalkan belajar dengan saling bekerja sama antara satu dengan yang lain.

Menurut Arsyad (2005 : 1) pengertian hasil belajar adalah adanya perubahan tingkah laku pada diri seseorang yang mungkin disebabkan oleh terjadinya perubahan pada tingkat pengetahuan, keterampilan, atau sikapnya. Perubahan diarahkan pada diri peserta didik secara terencana, baik dalam aspek pengetahuan, keterampilan, maupun sikap.

Matematika adalah ilmu yang mempelajari hal-hal seperti besaran struktur ruang, dan juga perubahan. mataematikan bukan hanya ilmu yang menerapkan konsep saja tetapi juga mengenai pembuktian dari kebenaran suatu konsep itu sendiri.dan secara tidak sadar kita telah menerapkan konsepkonsep matematika tersebut pada kehidupan kita sehari-hari

Jadi dapat di simpulkan belajar matematika sendiri merupakan suatu proses seorang siswa untuk mengerti dan memahami tentang matematika. Pada pembelajaran matematika harus terdapat keterkaitan antara pengalaman belajar siswa sebelumnya dengan konsep yang akan diajarkan.

Yang dimaksud dengan pecahan dalam matematika adalah bilangan rasional yang dapat ditulis dalam bentuk a/b (dibaca a per b), dengan bentuk dimana a dan $b$ merupakan bilangan bulat, $b$ tidak sama dengan nol, dan bilangan a bukan kelipatan bilangan b. Secara sederhana, dapat dikatakan pecahan merupakan sebuah bilangan yang memiliki pembilang dan penyebut

Berdasarkan hasil penilaian tema 7 kebersamaan sub tema 3 kebersamaan di tempat bermain pembelajaran 4 materi pecahan pada kelas II semester 2 SD Negeri Tengki 01 Kabupaten brebes pada mata pelajaran Bahasa Indonesia terdapat 7 siswa yang belum tuntas pada mata pelajaran PPKn terdapat 8 Siswa yang belum tuntas dan pada mata pelajaran Matematika terdapat 16 siswa yang belum tuntas dari jumlah 24 orang siswa .oleh sebab tersebut maka penulis merencanakan program perbaikan 
pembelajarandalam rangka meningkatkan upaya peningkatan hasil belajar tema 7 Kebersamaan sub tema 3 Kebersamaa di tempat bermain pembelajaran ke 4 dengan materi pecahan dengan model pembelajara kooperatif pada Kelas II semester 2 SD Negeri Tengki 01 Kabupaten Brebes Tahun pelajaran 2019/2020

Berdasakan latar belakang yang diuraikan peneliti tertarik untuk mencoba melakukan penelitian tindakan kelas yang di laksanaka dengan bantuan teman sejawat .peneliti berperan sebagai guru dan teman sejawat berperan sebagai observer judu dari penelitian ini adalah "upaya meningkatakn hasil belajar siswa pada materi pecahan dengan metode pembelajaran kooperatif' penelitian tersebut akan di lakasanakan di SDN Tengki 01 kabupaten Brebes tahun pelajarn 2019/2020

Dari uraian di atas peneliti merumuskan masalah sebagai berikut(1)Apakah penggunaan medel pembelajaran kooperatif dapat meningkatkan hasil belajar siswa di SD Negeri Tengki 01 Kabupaten Brebes tahun pelajaran 2019/2020 ?(2)Bagaimana hasil belajar siswa pada materi pecahan setalah menggunakan model pembelajaran koopratif pada siswa kelas II di SD Negeri Tengki 01 Kabupaten Brebes tahun pelajaran 2019/2020 ?

Tujuan penelitian yan hendak di capai adalah (1)Untuk meningkatkan prestadi belajar siswa dalam tema 7 Kebersamaan sub tema 3 Kebersamaan di tempat bermain pembelajaran ke 4 siswa kelas II semester 2 SD Negeri Tengki 01 Kabupaten Brebes tahun pelajaran 2019/2020.(2)Untuk mengetahui keefektifan penggunaan model Pembelajaran Kooperatif pada dalam tema 7 Kebersamaan sub tema 3 Kebersamaan di tempat bermain pembelajaran ke 4 siswa kelas II semester 2 SD Negeri Tengki 01 Kabupaten Brebes tahun pelajaran 2019/2020.Secara teoritis peneliti mengaharapkan penelitian ini bermanfaat dalam penerapan pembelajaran kooperatif dalam pembelajaran matematika khususnya pada materi pecahan.sedangkan secara praktis diharapkan bagi guru menambah wawasan serta dapat di jadikan rujuan dalam meningkatkan prestasi hasil belajar siswa khususnya materi pecahan di kelas II.

\section{METODE}

Metode yang d gunakan dalam penelitian ini adalah penelitian tindakan kelas (PTK). Kunandar (2008)Penelitian Tindakan merupakan suatu kegiatan yang dilakukan oleh pendidik atau bersama-sama dengan orang lain (kolaborasi) yang bertujuan untuk meningkatkan atau memperbaiki mutu proses pembelajaran didalam kelas. Hopkins (1993) Mengartikan Penelitian Tindakan Kelas untuk membantu seseorang dalam mengatasi persoalan secara prakstis yang dihadapi dalam situasi darurat dan membantu pencapaian tujuan ilmu sosial dan ilmu pendidikan dengan kerjasama dalam kerangka etika yang disepakati bersama. Menurutnya, PTK merupakan kajian yang sistematik dari upaya perbaikan pelaksanaan praktek pendidikan oleh sekelompok pendidik dalam melakukan tindakan-tindakan dalam proses pembelajaran. Berdasarkan refleksi mereka mengenai hasil dari tindakan-tindakan tersebut.Berdasarkan pengertian penelitisn tindakan kelas di atas dapat di simpulkan penelitian tindakan kelas merupakan suatu penelitian yang mengangkat masalahmasalah aktual yang dihadapi oleh guru atau dosen di lapangan. Masalah di dalam kelas atau ruang kuliah itu dapat diselesaikan atau dicari solusinya melalui Penelitian Tindakan Kelas (PTK).tujuan dari PTK sendiri adalah untuk meningkatkan kualitan proses pembelajaran melalui suatu tindakan dalam 
suatu siklus.dalam satu siklus mempunyai alokasi waktu 2x 35 menit dan mempunyai empat langkah yaitu:perencanaan,pelaksanaan tindakan,observasi da refleksi.

\section{HASIL DAN PEMBAHASAN}

Untuk memperoleh gambaran dari hasil peraikan pembelajaran yang di lakukan penulis pada prestadi belajar siswa dalam tema 7 Kebersamaan sub tema 3 Kebersamaan di tempat bermain pembelajaran ke 4 siswa kelas II semester 2 SD Negeri Tengki 01 Kabupaten Brebes tahun pelajaran 2019/2020. Pada dua siklus yaitu pra siklus, siklus I dan siklus II

Pada saat pra siklus kemampuan guru dalam menyusun perencanaan pembelajaran di rasa belum optimal dengan rata rata nilai 3,37 pada APKG 1.baik dari Model yang di gunakan pada saat pembelajaran kurang tepat ,Materi yang di ajarkan sulit untuk di mengerti siswa, fokus pembelajaran hanya berpusat pada guru serta kuranganya peranan orang tua dalam mendukung peserta didik. Kemampuan guru dalam menerapkan model pembelajaran kooperatif juga masih kurang terutama pada tahap aprepsepsi sehingga tidak dapat meningkatkan minat siswa dalam pembelajaran ,kurang merespon pertanyaan yang di berikan oleh siswa,siswa juga kurang maksimal dalam memanfaatkan waktu untuk berfikir sendiri dan dalam tentang materi yang di ajarakan sehingga dalam menyimpulkan materi pembelajaran kurang tepat dan jelas yang berimbas pada siswa tidak bisa mengikui kegiatan evaluasi dengan baik di buktikan dengan nilai siswa yang belum mencapai KKM.

Pada perbaikan pembelajaran di tema 7 Kebersamaan sub tema 3 Kebersamaan di tempat bermain pembelajaran ke 4 siswa kelas II semester 2 SD Negeri Tengki 01 Kabupaten Brebes tahun pelajaran 2019/2020.Pada siklus I kemempuan guru dalam merancan perencaanan pembelajaran pada materi pecahan dengan model pembelajaran kooperatif sudah mencapai peningkatan hal itu di tunjukan dengan ketercapaian nilai rata - rata syaitu 3,71 pada APKG 1 dimana pada kegiatan pra siklus dimana rata -rata sebelumnya 3,37.terdapat peningkatan kemampuan guru juga dalam pelaksanaan pembelajaran dalam materi pecahan menggunakan model pembelajaran kooperatif dari pada di pra siklus .namun masih dinilai kurang optimal diantaranya guru masih kurang dalam melakukan mobilitas di dalam kelas dalam pemberian contoh pembahasan ,kurang memanfaatkan media yang ada di lingkungan sekitar ,aktivitas siswa juga mengalami peningkatan namun belum menunjukan hasil yang optimal di lihat dari siswa yang belum bisa menyimpulkan materi secara tepat dan jelas .sebenarnya pada siklus satu ratarata nilai siswa sudah memenuhi KKM yaitu 69 dimana KKM satuan pendidikan yang di pakai 65 ,namun ada 11 anak dari 24 siswa belum mencapai 65 . Sehingga tingkat keberhasilan pembelajaran belum mencapai $75 \%$ maka perlu di tingkatkan perbaikan pembelajaran di siklus ke II

Pada perbaikan pembelajaran di tema 7 Kebersamaan sub tema 3 Kebersamaan di tempat bermain pembelajaran ke 4 siswa kelas II semester 2 SD Negeri Tengki 01 Kabupaten Brebes tahun pelajaran 2019/2020.Pada siklus II sudah mengalami peningkatan di bandingkan pada siklus I.kemampuan guru dalam merancang Rencana pelaksanaan pembelajaran (RPP) pada materi pecahan dengaan menerapkan model pembelajaran kooperatif mencapai 3,92 pda APKG 1. Kemamuan guru dalam melaksanakan kegiatan pembelajaran di nilai sudah optimal di lihat dari Pemberian apersepsi yang 
menarik. Guru memancing respon dengan mengajukan pertanyaan tentang kebersamaan di tempat bermain dilingkungan Guru memberikan penjelasan materi yang lebih mendalam.Guru menjelaskan materi pecahan dengan media konkret yang ada di sekitar, hal ini berkesinambungan dengan hasil belajar siswa yang juga mengalami peningkatan. dari data yang diperoleh teman sejawat dan juga juga data hasil test siswa ada beberapa hal yang ditemukan dalam penelitian pembelajaran di di tema 7 Kebersamaan sub tema 3 Kebersamaan di tempat bermain pembelajaran ke 4 siswa kelas II semester 2 SD Negeri Tengki 01 Kabupaten Brebes tahun pelajaran 2019/2020. Bahwa adanya peningkatan hasil belajar oleh siswa kelas II SD Negeri Tengki 01 Kabupaten Brebes Tahun Pelajaran 2019/2020 yang di ikuti juga dengan meningkatnya prestasi belajar.Prestasi belajar siswa dalam proses perbaikaikan pemebelajaran meningkat dari nilai kurang dari 65 pada pra siklus menjadi 69 di siklus 1 dan meningkat kembali di siklus 2 menjadi 82 .Umumnya pelaksanaan perbaikan pembelajarn berlangsung dengan lancar dan baik dengan nilai rata rata 69 dengan skala (1-100) di siklus 1 serta terjadi peningkatan nilai rata -rata menjadi 82 dari skala (1-100) di siklus yang ke 2

Perbaikan pembelajaran yang terjadi kelas II SD Negeri Tengki 0101 Kabupaten Brebes Tahun Pelajaran 2019/2020. Karena peneliti melakukan hal hal berikut pada siklus II mencakup :1)Memberi motivasi belajar siswa sehingga siswa menjadi bersemangat dalam melukukan kegiatan pembelajaran 2)Penggunaan media benda konkret sehingga siswa lebih mudah memahami materi yang di ajarkan 3)Penjelasan materi pembelajaran yang lebih mendalam 4)Pengaktifan siswa dengan model pembelajaran kooperatif sehingga siswa tambah semangat dalam belajar 5)Mengaktifkan siswa dengan Tanya jawab 6)Pemberian soal -soal latihan 7)Pemberian tugas kelompok di rumah.

Berbagai kegiatan pembelajaran yang dilakukan guru diatas pada Berbagai kegiatan pembelajaran yang dilakukan guru diatas pada di tema 7 Kebersamaan sub tema 3 Kebersamaan di tempat bermain pembelajaran ke 4 siswa kelas II semester 2 SD Negeri Tengki 01 Kabupaten Brebes tahun pelajaran 2019/2020. yang menjadi pusat penelitian adalah : (1)Aktivitas Belajar Siswa dengan begitu siswa harus memperoleh pengetahuannya melalui keaktifan dalam belajar .bukan hanya dengan mengikuti kegiatan daring bersama guru kemudian duduk diam mendengarkan penjelasan dari guru kemudian mengerjakan soal,tetapi siswa juga harus aktif di dalam kelas seperti melakukan Tanya jawab dengan guru. Karena pada dasarnya belajar merupakan aktivitas antara individu dengan individu.(2)Hasil Belajar SiswaHasil belajar siswa adalah hasil pengukuran kemapuan siswa setelah terjadinya proses pembelajaran dengan melakukan proses evaluasi . Hasil belajar pada siswa sangat tergantung pada pemahaman siswa mengenai materi yang diajarkan pada saat proses pembelajaran.sedangkan pemahaman siswa juga bergantug pada aktivitas belajar siswa.Romizoswki (1982) menyebutkan dalam skema kemampuan yang dapat menunjukan hasil belajar yaitu: 1) keterampilan kognitif berkatian dengan kemempuan membuat keputusan memecahkan masalah dan berpikir logis; 2) keterampilan psikomotor berkaitan dengan kemempuan tindakan fisik dan kegiatan preseptual; 3) keterampilan reaktif berkaitan dengan sikap, kebijaksanaan perasaan, dan self control; 4) keterampilan interaktif berkaitan dengan kemempuan sosial dan kepemimpinan. Gagne (1979) menyebutkan ada lima tipe hasil belajar yang dapat di capai oleh siswa 1) motor skills; 2) verbal information; 3) intellectual skills ;4) attitudes; 5) cognitive strategies 
(3)pengamatan guru dalam aktifitas pembelajaran.Secara keseluruhan hasil dari penelitian tindakan kelas dalam materi pembelajaran pecahan berhasil mengalami peningkatan melali upaya tindakan perencanaan dan pelaksanaan pembelajaran melaui model pembelajran kooperatif .pelaksanaan pada penelitian tindakan kelas ini menggunakan model pembelajaran kooperatif pada materi pecahan di kelas II SDN tengki 01 Kabupaten Brebes pada tahun pelajaran 2019/2020.mengalami peningkatan hasil belajar yang signifikan.

Tabel 1. Perbaikan di siklus 1

\begin{tabular}{cccc}
\hline No & Nilai (x) & Frekuensi (f) & (fx) \\
\hline 1 & 100 & 3 & 300 \\
2 & 90 & 3 & 270 \\
3 & 80 & 2 & 160 \\
4 & 70 & 5 & 350 \\
5 & 60 & 4 & 240 \\
6 & 50 & 7 & 350 \\
& Jumlah & 24 & 1670 \\
\hline
\end{tabular}

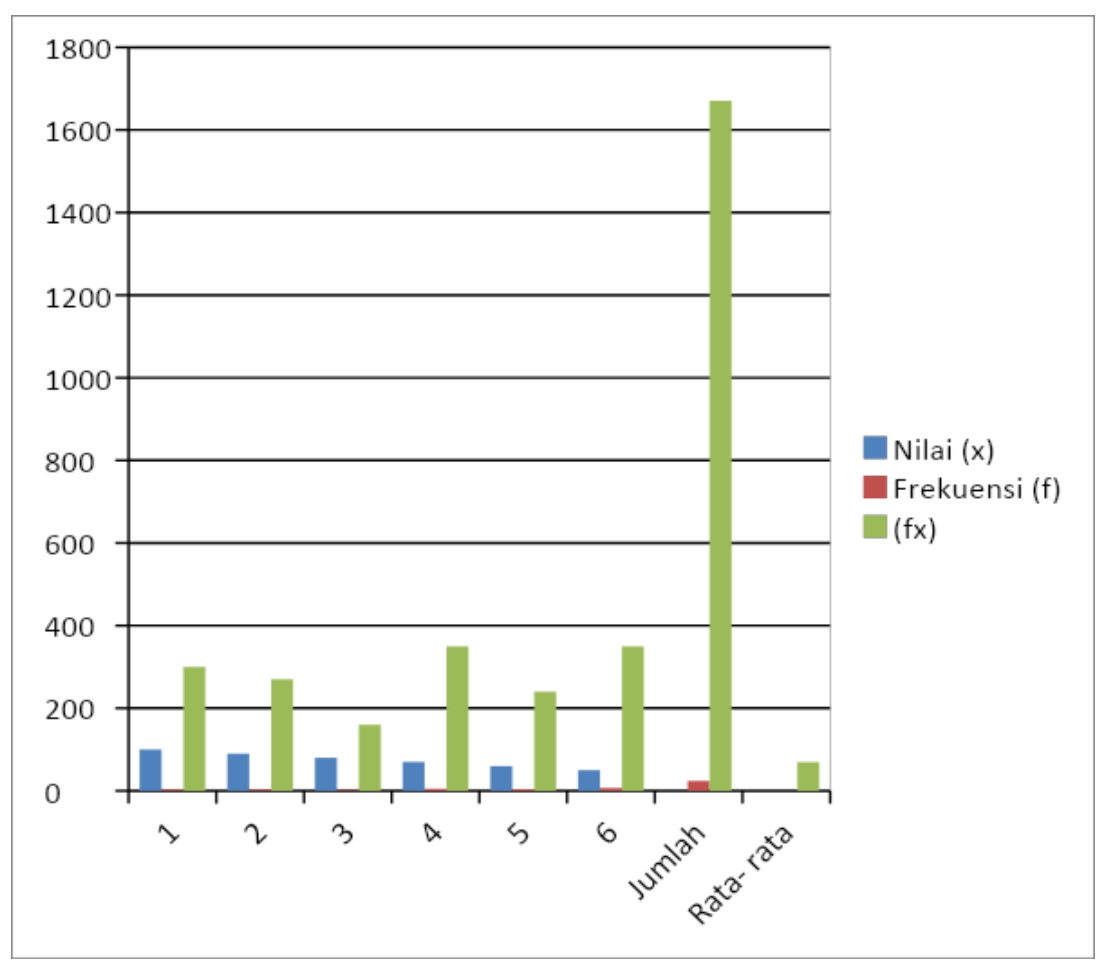

Gambar 1. Hasil Observasi Keterampilan Proses Sains 


\section{SIMPULAN}

Dari hasil yang dibahas dihalaman sebelumnya dapat disimpulakan bahwa perbaikan pembelajaran dengan model pembelsjsrsn kooperatif tema 7 Kebersamaan sub tema 3 Kebersamaan di tempat bermain materi pecahan di kelas II SD Negeri Tengki 01 Kabupaten Brebes tahun pelajaran 2019/2020. berjalan dengan lancar dan baik membuktikan dapat :

1. Peningkatan aktivitas belajar siswa deangan adanya peningkatan hasil belajar siswa yang lebih baik. Dari 24 siswa peningkatan aktivitas pembelajar nmencapai kurang dari $65 \%$ dan meningkat di siklus 2 menjadi $100 \%$

2. Prestasi belajar siswa dari nilai rata-rata yang tadinya kurang dari 65 menjadi 69,50 di siklus 1 dan mengalami peningkatan pada siklus 2 menjadi 82,03

3. Peningkatan efektivitas tersebut dikarenakan aktivitas sebagai berikut a) Guru Memberikan motivasi belajar pada siswa sehingga siswa terpacu giat dalam belajar walaupun secara daring b)Penggunaan media yang tepat sehingga meperjelas materi yang disampaikan.c)Meggunakan model pembelajaran yang tepat yaitu model pembelajaran kooperatif sehingga siswa lebih paham dengan materi yang di jelaskan.d)Dengan adanya pembelajaran berkelompok siswa mampu memecahan masalah dalam pembelajaran secara bersama.e)Adanya peran guru dalam memancing siswa untuk melakukan Tanya jawab mengenai materi yang diajarkan.f)Pemberian soal -soal latihan yang mudah di pahami maksudnya (tidak berbelit-belit).g)Melakukan control pembelajaran dengan memberikan tugas rumah. Baik secara Individu maupun kelompok.

\section{DAFTAR PUSTAKA}

Andriani,Durri.2017.Metode Penelitian.Tangerang Selatan : Universitas Terbuka.

Anitah W,Sri.2014.Strategi Pembelajaran di SD.Tangerang Selatan : Universitas Terbuka.

Heruman. (2008) Model Pembelajran Matemtika di Sekolah Dasar. Bandung. PT.Remaja Rosdakarya

Rusman.(2012). Model Model Pembelajaran Mengembangkan Profesionalisme Guru Edisi Kedua. Jakarta : PT.Raja Grafindo Persada.

Sukaji (2008). Pembelajaran Operasi penjumlahan Pecahan di SD Menggunakan Berbagai Media . Yogyakarta : Pusat Pengembangan dan Pemberdayaan Pendidikan dan Tenaga Kependidikan Matematiak 